\title{
SPECIFICS OF THE SCIENTIFIC RESEARCH \\ OF FAMILY AND MARRIAGE RELATIONS IN SOCIAL SCIENCES IN THE POSTMODERN PERIOD
}

\author{
Ganna Kravchenko \\ Postgraduate Student at the Department of Philosophy, Sociology and Management \\ of Sociocultural Activities, South Ukrainian National Pedagogical University \\ named after K. D. Ushynsky, Ukraine \\ e-mail: Greenchester@ukr.net,orcid.org/0000-0002-7791-2716
}

\section{Summary}

This article presents the comparative analysis of scientific interests and concerns in the domain of family and marriage relations in such social sciences as history, philosophy, psychology, law, sociology, demography and pedagogics.

The place and importance of philosophy are determined; its influence on the progress of the aforesaid sciences is also analysed. The place, role and importance of social philosophy are discovered.

The subject field of each aforesaid science is studied thoroughly. Also the subject field of social philosophy is discovered and distinguished, and its scientific concerns in researching family and marriage relations are studied.

It is found out that each of the scientific disciplines mentioned in the article delves into and studies family, marriage and family-marriage relations in its own sight with its own scientific concern, approach, in accordance with its subject and method of research. The author sets distinct limits of scientific researches of each mentioned discipline as well as social philosophy.

An opportunity to study family and marriage relations is found from the point of view of various sciences by engaging herewith their research tools. The focus is made on the fact that this combination makes it possible to enrich every scientific discipline with some additional knowledge.

In the article, the author proves that the contemporary period of postmodern and world globalisation of society are displayed in family and marriage relations.

The author proves the correlation between transformation processes going in the period of postmodern in different fields of public life and changes in family and marriage relations.

Keywords: globalization, society, social institutes, public relations, family life, postmodernization of society.

DOI: https://doi.org/10.23856/3835

\section{Introduction}

Each of us gets the first lessons of life in the family. The family creates an environment where a man grows, public relations develop. Family and marriage are two individual social institutes closely interrelated. It is possible to say that these institutes are basic for the society. As such, family and marriage presently are targets of research of the entire line of social sciences, e.g. of such sciences as history, philosophy, psychology, jurisprudence, sociology, demography, pedagogics and some others. However, every science has its own target and method of research, i.e. it has its own specifics. Therefore, every science analyses and studies family and marriage as well as relations originating among entities of these institutes from various viewpoints in 
accordance with the subject and method of research of this science. Hence, the study of family and marriage relations has an interdisciplinary context.

Considering those changes happening in the world and the fact that the fact-based science and fact-based knowledge are developing in this contemporary period of postmodern, it becomes necessary to determine an area of scientific interests in the field of family and marriage relations in the said sciences. We believe that it is necessary to determine a place, role and importance of social philosophy in studying family and marriage relations. The timeliness of this article consists in this in our opinion.

The objective of this article is to find the essence of scientific interests and concerns of the aforementioned scientific disciplines in the field of family and marriage relations. The scientific-research task of this article is to find out what exactly planes of family and marriage relations are studied by different social sciences, to determine and distinguish the subject field of social philosophy in studying these relations as well as to set distinct limits of scientific researches of every discipline mentioned in the article.

In this research, we apply the principle of objectivity, historic principle as well as principle of comparativeness. Besides, we use the closely interrelated logical method and chronological approach in the course of this research. In studying family and marriage relations, it is allowed to use methods of exact sciences as the specifics of the said relations is in that they are studied by different sciences.

\section{Exposure of the main material}

The contemporary period of postmodern and worldwide globalisation of society are changing the world; the process of uniting the world in one system is going. Certainly, all these changes have influenced family and marriage relations either. Changes occur in them as in the society. For this very reason, society is studied by many different sciences from different perspectives, and for quite some time already. However, the scientific studying of the subject of family and marriage relations has started recently. As said, family and marriage as well as relations arising among entities of these institutes are presently studied and explored by quite many sciences. It is happening because of the fact that such family and marriage relations within the subject field of various sciences, disciplines arise during the family and marriage creation and functioning. Every science studies family and marriage relations from its perspective with its individual approach, subject and method of approach. Thus, we assert that family and marriage relations can be regulated by standards, methods and tools of different sciences.

Meanwhile, the science of the period of postmodern is characterised with such a feature as striving not just to find an answer to any question, but to give a clear unambiguous answer to it. That is why and in view of the fact the we study the postmodernisation of family and marriage relations at the contemporary stage of the society development from the viewpoint of social philosophy, we have a priority to set the distinct limits in studying these relations from the perspective of social philosophy. Therefore, we decided to distinguish scientific interests and concerns and to determine planes of family and marriage relations studied by such sciences as history, pedagogics, demography, psychology, law, sociology and social philosophy.

\section{Starting with history}

History as science is one of the oldest. It studies the past, life of society, its growth, course of events. The French historian of the Jewish origin, Mark Block, believed that history is science about people and their life in the society. In his scientific work "Apology of Histories 
or Historian`s Art", he wrote very poetically: 'History is a science about people in the time... Behind the visible landscape outlines, tools or machines, grey documents and institutes that are really far from those who created them, history wants to see people' (Blok M., 1973: 18).

From our viewpoint, history is a viewing of historic events, end of historic cycles first of all. It is possible to say that it studies the past of the human society and its modern times. Family and marriage relations are a part of the human society life. So one can assert that this science reveals patterns of the public life growth in various forms (especially in the form of family, marriage) in the measurements of space and time. Historic processes have a direct influence on events in the life of a human, particularly marriage in general. These events are extremely different and relate to the development of different sides of relations and activities of historic persons. Studying such historic processes is a purport of history.

History is a multi-branch science. It comprises a set of specific historic knowledge. Thus, for example, quite a young branch of historic knowledge, social history, expressly studies various social groups and relationships among them, particularly the role and functions of family as one of social groups, in public structures and processes, studies the influence of historical public movements on family and family-marriage relations, social conflicts.

Hence, history studies a man in various manifestations of his life and activities - in economy, politics, culture and so forth. And all of this goes on the back of family as a human's life goes in his family, marriage or out of the marriage in different times. That means that due to the historic science we are able to see how family and marriage relations of people were in different times and different countries.

\section{Considering the next science - pedagogics}

Pedagogics as subject area is one of the most ancient. We can assert that it is integral in its nature for history and human progress as pedagogic thoughts were first born and began elaborating in Ancient Greek, Ancient Eastern and Medieval philosophy and theology. Pedagogic ideas and principles, which were in the philosophic works of Platoon, Aristotle, Socrates, Democritus, Confucius and Quintillian, caused the origin of theoretical pedagogic concepts that formed a basis for an integral system of global education. Meanwhile, pedagogics was first distinguished from philosophy only in the beginning of $17^{\text {th }}$ century with the efforts made by the English philosopher, Francis Bacon, who distinguished pedagogics and called it as a science separated from philosophy in his scientific work "About Dignity and Growth of Sciences".

Among our national activists-educators, we need pay our attention to the works of the world-class Ukrainian philosopher, theologian, prose writer, poet and teacher, Grygoriy Skovoroda. He made the focus on the need of natural education of children, obligatory teaching in the native language, insisted on the requirement of full development of the human personality. However, apart from this, Skovoroda proved the importance of education in the family in his works, as "the first natural educators and mentors of youth are parents" from his point of view (Shvetsova I., 2012: 180). In his parables, he displayed his views of family and marriage relations. So, for example, he propagated deep respect of parents by children, about the obligation of parents not just to give birth to physically healthy children, but to give a right education to them. In his stories and parables he revealed the essence of relations in the family, focused the attention on the importance of kind relations, feeling of gratitude, and showed his insights in family values.

Therefore, we see that the process of education appeared with the formed human society. Methods of education were developing in line with the human progress in accordance with different historical epochs. 
At the modern stage, pedagogics is a multi-branch social science that functions and develops in conjunction with other sciences. It combines the information from almost every social science about children, influence of the family and family and marriage relations between parents on the child, about laws of development of educational social processes affecting the human evolvement and progress in general.

We see that pedagogics as science studies family as the most important factor in the educational process of every child as the child comes to the company of his or her parents and next of kin. Correspondingly, from the very beginning family and parents help the child to socialise himself/herself in our world. It is important that family members, first of all parents, demonstrate and pass the system of values, moral and social behaviour standards to their child. From this very perspective it is impossible to overestimate the place and role of family in the education of children.

Having analysed the subject field studied by the science of pedagogics, we can conclude that this science looks at family, marriage and family-marriage relations in terms of their influence on the education and process of socialisation of children. Scientists-educators demonstratively prove that the key to the right and quality education in the family directly depends on inner relations in the family and mutual respect, care and patience of family members to one another.

\section{Studying demography as the next scientific discipline}

Demography is a science about principles of reproduction of population. We think that this science helps to understand the modern processes going in the society and to see and to think over the factors impacting these processes. The authors of the encyclopaedia dictionary "Human Population" state, “... as a specific science, demography studies principles and social conditions of birth rate, deaths, production of marriage couples and families, reproduction of population in general as unity of these processes. It studies changes in the age-sex, marriage and family structure of population, correlation of demographic processes and structures as well as principles of change of the overall number of population and families as a result of interaction of these phenomena" (Melikian G., 1994: 113).

Therefore, we see that family and marriage as social institutes also belong to the complex of objects of demography.

Demography considers family as one of the conditions of reproduction of population. Any family develops and obtains certain events during its existence. The complex of family events creates a line of stages, the sequence of which is called together as a life cycle of family. We would like to point it out that science of demography traditionally pays a great attention to the study of the family life cycle. And in this whole range of functions performed by the family, demography studies only those related to the demographic functions, i.e. reproductive, educative functions and functions that create conditions assisting in keeping life, i.e. recreational and theraupetical. Regarding marriage, demography considers marriage as a factor of creation of a family and birth of children. At the same time, this science is interested not only in the registered marriage, but in marital relations without legal registration as illegitimate birth is related to them. Moreover, this science studies the process of breakdown of married couples - divorces.

So we can see that demography studies different aspects of the problematics of family, marriage and family-marriage relations. The demographic analysis comprises various methods of study of the marriage rate. 
Having analysed the said practical tasks of demography, we can conclude about the fact how closely they are related with one another. By means of their complex analysis and resolving, there is an opportunity to obtain that complete and comprehensive characteristics of trends and principles of the society demographic development.

\section{Studying now psychology as a science}

Analysing quite a great deal of scientific sources, we arrive at an idea that since the age of Ancient Greece and to the development of natural and social sciences and their distinguishing from philosophy only philosophers tried to understand the essence of a man and his interactions with the physical and social environment. Aristotle was the first Ancient Greek philosopher who suggested a concept of human soul as a function of his body, and not of an external phenomenon influencing it (Godfrua Jo., 1992: 60). The word "psychology" as a term describing the science about soul was first used in 1590. It was done by the German philosopher, scientist, doctor Rudolph Goclenius in his scientific work "Psychology, as About the Human Perfection, About Soul and Its Origin In Primis". Meanwhile, this event did not result in distinguishing psychology and its specific functioning. Only in 1879 at the University of Leipzig, the first psychological laboratory was established. It was headed by Philosopher and concurrently Psychologist Wilhelm Wundt. He started experimental scientific researches of the human mind in his laboratory (Godfrua Jo., 1992: 64). Right since then psychology has been considered as an independent science.

On grounds of the aforesaid, we can assert that psychology as science is quite young. The interesting fact is that the apprehension of the target and subject of this science was changing in line with the stages of development of psychology as science. However, presently we have not found a single generally accepted definition of subject of psychology. Due to the aforesaid, the idea of our national scientist, O.A. Melnyk, about the existence of particular "specifics of certain approaches to the understanding and study of the subject of the psychological science" is very important and interesting at the same time from our point of view (Melnyk O., 2011: 141). In his article "Theoretical Fundamentals of the Formation of the Subject of Psychology", O.A. Melnyk writes that 'for the psychologist mind as a subject of psychology is firstly a human mind. So the subject of psychology at the philosophic-mindset level of problems is in the thoughts about problems of the human`s being in the world. The philosophic concept of human being, its essence and place in the world is that context where the subjective self-determination of the psychologist's thinking happens' (Melnyk O., 2011: 141).

The main research target of psychologists is a man as an entity entering many interactions with the world as an entity of various activities, communication and cognition. Ones of these relations which a man entering as an entity are family-marriage relations. At the contemporary level of progress, psychology as science pays quite a great deal of attention to the study of human behaviours in family and marriage, studies inner psychological processes going in the family-marriage relations, researches the role interaction of partners in their marriage and intimate communication, relations of children and their parents, and gives practical recommendations for improving these relations.

Thus, family psychology is a branch of the psychological science, the subject of study of which is principles of the family functioning, manifestations and mechanisms of family and marriage relations (Stoliarchuk O., 2015: 5).

By contrast with social philosophy and other scientific disciplines that study family and marriage relations, family psychology finds the real reasons for marriage, finds and studies the 
causes of families becoming troubled, can give an answer to a man how he can combine his personal life with the family life in general and help adjust to the life in marriage, family, after divorce or during the formation of a new (second) marriage.

Summarising the aforementioned, we can come to the conclusion that family psychology studies the psychological peculiarities of every individual family and every individual marriage.

\section{Studying law as our next science}

The history of development of law is closely related to the origin and development of states as phenomenon. Law appeared with the origin of the first state as far back as the existence of the Ancient World. It was natural as the state is an organisation joining not only relatives, but people in general who live in a certain territory. With the passage of time it became clear that only customs, traditions, religious beliefs and moral principles were not enough to govern relationships among people. Law as a social regulator appeared then.

Thus, the purpose of law, in our opinion, is in governing all the aspects of life of the human society. Its essence is determined by the economic and political system of the state. It is influenced by traditions and common ideology existing in the state.

In a similar vein, law with its nature as concept, phenomenon, scientific discipline greatly differs from all those social sciences analysed by us before. First of all, it is due to the fact that law standards have an imperative nature, i.e. they are mandatory for implementation. Besides, law expresses the principle of formal equity among people in the society.

Law has its internal organisation, that is, a system. The system of law consists in the unity and coherence of legal rules within one individual state as well as in dividing all the standards of law of the country according to the branches of law and institutes of law as per an object of regulation. Nowadays, our state has quite many branches of law. However, according to the topic of our dissertation research, and in view of the purpose of this article, we are directly interested in the branch of Family Law of Ukraine.

Outstanding Ukrainian Legal Scholar V.V. Kopieichykov proposes the following definition: "Family law is an aggregation of legal standards and principles that regulate and protect personal and related property relations of individuals arising out of marriage and family belonging. That is, this law governs relations of spouses regarding the marrying procedure, personal and property relations between them, procedure and terms of marriage termination, relations of parents and children, other relatives. Family law of Ukraine regulates and protects relations of adoption, custody and care, etc." (Kopieichykov V., 2006).

Hence, by summarising the aforesaid, we can make a conclusion that family law opposed to all the other scientific disciplines studied above and next to be analysed does not study, analyse, treat of family and marriage. And with the assistance of the government, it protects families, marriages, family members, spouses and regulates specific relationships originating in families and marriages. The principle distinction and specifics of this scientific discipline consist in this fact.

\section{One more social scientific discipline - sociology}

Sociology is a science that studies society. This science is deemed as quite young because sociology as independent branch of scientific knowledge appeared only in the $40 \mathrm{~s}$ of $20^{\text {th }}$ century. Alongside, the human race has been interested in the formation and development of societies since ancient times. The first knowledge about society based on the ideas contained in the 
ancient myths and legends. Philosophy with the knowledge about the world originated on the basis of mythology. Gradually, with its development and within its ambit, a particular aspect of knowledge about social phenomena - social philosophy was formed. So we may assert that sociology originated on the principles of social philosophy due to the progress of ideas about society and man.

This scientific discipline differs from all the previous sciences by the fact that it studies society through the lens of all those social processes and relations happening in the real life.

Russian and concurrently American Sociologist and Educator Pitirim Oleksandrovych Sorokin though that 'Sociology studies phenomena of people's interacting with one another on the one hand, and phenomena appearing in this process of interaction on the second hand. This definition outlines certain phenomena studied by sociology. It says that all other forms and types of interaction are set aside from the area of sociological studies... Our sociology is homo-sociology. It deals with human interactions only' (Sorokin P., 1920: 2).

The aforesaid proves that this science studies the social aspect of life and relations among large and small communities of people and among people themselves who are in such communities. So to study family as a social institute, its functions and importance for the society, an independent subject area was created - family sociology.

Scientists-sociologists were actively working on the concept of family. Some scientists still believe that the concept of family elaborated by scientific sociology is the most correct and comprehensive. So, for instance, Professor M.D. Shymin gives the following definition of family: 'Family is a specific form of social life of people conditioned by the society economic system, based on marriage and or family including the whole aggregation of relations (between a husband and a wife, parents and children, among different generations) occurring on the basis of common all-round activities of its members where either society needs (in the physical and spiritual manifestation of a human personality, in securing a normal common life of people in the field of private life) or individual's needs (in sexual relationships, personal family happiness) are implemented" (Shymin N., 1989: 21).

Therefore, by analysing the aforementioned, we understand that the scientific discipline of family sociology distinguishes the concepts of family and marriage, and studies them as two standalone but interrelated most important social institutes that have top places in our society.

\section{Studying the subject field of social philosophy}

From our viewpoint, philosophy is a special subject area that studies the most common principles of development of nature, society, human being and world in general. Philosophy is intended to find answers to those questions, which no other sciences can find answers to.

The specifics of the subject of philosophy is that it constantly changes and is specified. Even presently, the subject of philosophy gets a new content. It is especially challenging now in the period of postmodern when revolutionary changes are happening in various aspects of our life. It happens because of the fact that life does not stand still, the society grows, human needs change, new questions arise, which the human race try to find answers to. Therefore, it becomes clear that the philosophic thought has been developing for its whole history. But it accumulates the explored on the one hand, and enriches with new knowledge on the second hand. All this leads to the fact that the research target of philosophy is limitless. And here is the exclusive specifics of philosophy as a science and discipline as well.

Furthermore, as said by A.M. Oriekhov, "Philosophy is not a dividable "monolith"; to the contrary, it can be broken in its middle, differentiated to many sciences (aspects, teachings) 
used to be called as "Philosophic sciences". Every philosophic science elaborates its aspect of philosophic knowledge" (Oriekhov A., 2011: 8). One of such philosophic sciences is social philosophy that studies the society. But it is very simplified elementary definition. From our point of view, the most expanded definition of this science and discipline is given by A.M. Oriekhov who thinks that 'social philosophy is a science about the fundamental laws and principles of society development and a theory about the essence and values determining this development. Social philosophy is a scientific theory about boundary fundamentals of the society' (Oriekhov A., 2011: 11). Moreover, we agree with his idea concerning the purpose of social philosophy. The scientist thinks that 'the main aim of this science is to generalise, to integrate philosophic and private scientific knowledge about society to the rational and coordinated ensemble of theories and concepts, to elaborate the main axiological elements and features of this ensemble' (Oriekhov A., 2011: 9).

The subject of social philosophy is society as a coherent social system and laws of functioning and growth of society. It means that social philosophy studies and explains different public phenomena and processes at the macro level, i.e. at the level of the whole society as a social system that develops independently and reproduces itself (Lavrinenko V., 2004: 384). Social philosophy considers society as different processes of public life and result of activities of people who realise their needs in certain historical conditions. It characterises the human progress in general. Besides, it studies the interaction of different elements, different segments of society. In this context, social philosophy studies the practical activities of people and their social relations. During the interaction, people come to various relations, which might be industrial, educational, family-marital or just family ones, kindred relationships, etc. All these relations together build the structure of the society, as any society is people in the first instance!

Alongside, social philosophy does not study a human being as a standalone personality. This science views a human being as part of somewhat community. One of the features characteristic namely for this scientific discipline consists in this. One of such communities is family. Correspondingly, family, marriage and family-marriage relations belong to the subject area of social philosophy.

It should be pointed out that the attention was first paid to the role and importance of family and marriage for a man, in particular and for the government in general by philosophers. Ancient Greek philosophers Platoon and Aristotle are deemed to be fathers of the definition of the status of family. So, from the very beginning, family and marriage as well as relations appearing within these institutes were first studied right in the subject field of philosophic thoughts.

Nowadays, the problems of family and marriage relations in social philosophy have become more timely due to the fact that many stereotypes which were based in the ideas about the society role and place in the family and marriage between the wife and husband broke down in the period of postmodern, i.e. the ideas about gender changed. Moreover, the ideas about family and marriage themselves greatly differ in the period of postmodern from the previous periods. Even the sense of life is seen by a modern man in other things.

Besides, the changes going in the Ukrainian society today result in the transformation of family functions. Professor Yevgen Ruslanovych Borinstein accentuates the fact in his monography "Specifics of the Sociocultural Transformation of the Modern Ukrainian Society" that 'New integrational and regulative mechanisms have appeared in Ukraine. The result of ruining the traditional social integration structures and mechanisms is in a growing massive detachment, anomy (according to E. Durkheim) from the present and angst.' (Borinstein Ye., 2006: 851).

The peculiarity of the social-philosophical conceptualisation of family and marriage is that they are considered as specific, very important social institutes. This understanding comes 
out of the fact that family performs one of the most important functions for the society through family and marriage relations - generation of new members of society, implementation of their initial socialisation. Furthermore, the social-philosophic conceptualisation of contemporary family and marriage relations takes into consideration one of the characteristic manifestations of the period of postmodern, i.e. aspiration of people to individualise themselves and to self-realise. By the virtue of social philosophy, we are able to see and to analyse the evolution processes happening in the family, marriage and family-marriage relations for centuries. And, in our opinion, it is very significant as because of this we can forecast a further development of family and marriage relations in Ukraine. It is also very important and needed right in the present times.

\section{Conclusions}

Summarising the aforesaid, it should be pointed out that we want to determine the place and importance of philosophy as well as to show its impact on the progress of other sciences in this article, as philosophy is at the onset of many sciences. From this very perspective, it is sometimes named as "mother of all sciences".

In addition, we establish scientific interests and concerns in the area of family and marriage relations amid various scientific disciplines and determine and distinguish the subject area of social philosophy in the research of these relations in the course of our work. Besides, we set distinct limits of scientific studies of every discipline mentioned in the article.

On grounds of the aforementioned, we may come to a conclusion that many scientists with different scientific interests and concerns worked on the issues of family, marriage and family-marriage relations in the past, and work on these issues nowadays. That is, the problems of family and marriage are studied by scientists in different times in terms of different scientific disciplines. However, family and marriage relations are still topical because some of their aspects have not been explored yet, and others have an absolutely different interpretation in the light of postmodernisation of the modern society. Thus, in particular, the attempts to give a definition of family and marriage till nowadays cannot be deemed as successful and completed. Every science studies these targets in its sight. So there is a great deal of definitions. But the understanding of family as initial cell of society was elaborated specifically by philosophers.

We also pay our attention to the fact that people say and write a lot about the problems of family and marriage in our state nowadays. When the problems of family and marriage relations are mostly studied in psychology, sociology, demography and law, to the contrary, a less attention is put to these relations lately in social philosophy. Due to this, we think that these circumstances should be corrected as the deep transformations of various aspects of social life with family-marriage relations happen in the period of postmodern. In our opinion, the social-philosophic theory about marriage and family has a special significance during this time. So we believe in the need of a deep special philosophic apprehension of such changes going nowadays in the institutes of family and marriage in Ukraine and worldwide as the social-philosophic research assists in creating an integral picture of scientific viewpoints to family and marriage relations and their dynamic development over time.

We also come to a conclusion that the institutes of family and marriage as well as family-marriage relations originating within these institutes at this stage of their development require a more detailed overthinking of legal, psychological, mind and social-philosophic aspects. The fact of some aspects of family and marriage relations belonging to the subject area of various sciences enables us to engage tools of such sciences for regulating these relations 
and resolving tasks set. We believe that love, mutual respect, care about parents and other dear people, care about the education of children are important fundamentals that originate in the family and are kept in our society with its aid.

The perspectives of future scientific elaborations in this aspect are associated with a deeper study of family and marriage relations in terms of social philosophy as some aspects of these relations have changed and have an absolutely different interpretation in the context of postmodernisation of the society.

\section{References}

Blok, M. (1973). Apologiy istorii ili remeslo istorika [Apology of history or the historian 's art]. Moscow: Nauka. [in Russian]

Borinstein, Ye.R. (2006). Osobluvosti sociokulturnoi transformatcii suchasnogo ukrainsikogo suspilistva: monographia [Specifics of the sociocultural transformation of the modern Ukrainian society: monography]. Odessa: Astroprint. [in Ukrainian]

Godfrua, Jo. (1992). Chto takoe psihologia: v 2-h tomah [What is psychology: in 2 volumes]. Translated from French. Moscow: Mir. [in Russian]

Kopieichykov, V.V., Kolodiy A.M. (2006). Pravoznavstvo [Law]. Kyiv: Yurinkom Inter. [in Ukrainian]

Lavrinenko, V.N. (2004). Philosophia [Philosophy]. Moscow: Jurist. [in Russian]

Melnyk, O.A. (2011). Teoretuchni osnovu formuvannia predmeta psychologii [Theoretical principles of the formation of the subject of psychology]. Kharkiv: Visnuk Kharkivckogo natcionalnogo universutetu imeni V.N. Karasina. Seria: Psychologia. Vupusk 47 (№ 981). [in Ukrainian] Melikian, G.G. (1994). Narodonaselenie: enceklopedicheskiy slovar [People population: encyclopaedia dictionary]. Moscow: Bolshay Rossiyskaiy Enceklopediy. [in Russian]

Oriekhov, A.M. (2011). Sotcialnay philosophia: Predmet, strukturnue profile i vuzovu na rubeje XXI veka: monographia [Social philosophy: Subject, structural profiles and challenges at the cusp of 20 $0^{\text {th }}$ century: monography]. Moscow: Knijnuy dom "Librikom". [in Russian]

Shvetsova, I.V. (2012). Vukorustannia idey G. Skovorodu u vuhovanni povagu do lydunu [Use of ideas of G. Skovoroda in the education of respect to a human]. Kherson: Naukovi zapusu. Seria "Psychologia i pedagogika". Vupusk 21. [in Ukrainian]

Shymin, N.D. (1989). Simya kak obschestvennoe yavlenie: Oput sotcialno - philosophskogo analiza [Family as social phenomenon: Experience in the social-philosophic analysis]. Voronezh: Izdatelstvo Voronezhskogo Universiteta. [in Russian]

Sorokin, P. (1920). Sistema sotciologii. Tom 1. Sotcialnai analitika [System of sociology. Volume I. Social analytics]. Petrograd: Kolos. [in Russian]

Stoliarchuk, O.A. (2015). Psichologia suchasnoi simii [Modern family psychology] Kremenchuk: Publishing of Shcherbatykh O.V. [in Ukrainian] 